\title{
THE EFFECTIVENESS OF INTEREST-FREE LOAN FINANCING (QARDHUL HASAN) AS THE SOCIAL IMPLEMENTER OF ISLAMIC BANK TO REDUCE POVERTY IN SURAKARTA
}

\author{
Junaidi; Zeni Lutfiyah; Moh. Adnan \\ Faculty of Law, Universitas Sebelas Maret \\ E-mail: junaidi@staff.uns.ac.id
}

\begin{abstract}
The function of Islamic banks is not only to eliminate the interest system in its operational system, but also take a role to improve social welfare. Islamic banks have programs that can be used in the context of eradicating poverty, it is interest-free loans (qardhul hasan). Interest-free loan financing (qardhul hasan) is a social loan which is provided free of charge without any charges except returning its capital. This study is intended to examine how the implementation of interest-free loans (qardhul hasan) by Islamic bank and to know the extent of which the financing of interest-free loans (qardhul hasan) can alleviate poverty in the society. This research is none of doctrinal research. The research location is in Islamic bank in Surakarta. The output of this research is publication on national journal.The financing of Al-qardhul hasan itself has not got attention from Islamic bank as the realization of the social function of Islamic banking. Islamic banking products are more oriented to the the programs which contains the value of profit / profit so that interest-free loans (Al-qardhul Hasan) has not taken yet as a role in efforts to alleviate poverty.
\end{abstract}

Keywords: qardhul hasan, Islamic bank, poverty alleviation.

\section{A. INTRODUCTION}

Nowadays, poverty is still a serious problem that should be solved by the government and society. Based on the data In 2014, based on BPS data the number of poverty reached 28.28 million people or reached 11.25 percent by the population total. He said that although the percentage of poor population tends to decline, the number of poor people continues to increase. This is seen since at least 2013. In the year 2013, the poor 11.37 percent with the number reached 28.07 million people. The number of poor people in 2015 is predicted to reach 30.25 million people or about 12.25 percent of the total Indonesia's population. (http://www.republika.co.id/berita/nasional/umum/14/12/23/nh191e-pendudukmiskin-di-2015-diprediksi-3025-juta-jiwa)accessed on March 26, 2015 at 09.15 WIB. 
One of the advantages of Islamic banks is to make the debtor as a business partner. For example, in implementation the principle of profit sharing (akad musyarakah and mudharabah) necessitates a risk of joint loss for both the bank and the debtor. The success of the debtor's business is as an indicator of the success of the Islamic bank, while the application of the interest system in the conventional banking necessitates a definite profit from the debtor in the percentage, even if the debtor itself suffers a loss in its business. In other words, the bank does not want to know the difficulties of its clients. This benefit becomes a point for Islamic banks to be a friendly financial institution with the community. Islamic banks can proactively empower their debtors both in terms of performance improvement and moral coaching.

The Islamic bank products are not only business-oriented, but also as socio economical benefits. One of the products of Islamic banks that have a social function is the financing of interest-free loans (qardhul hasan). The financing Al-qardhul hasan is a finance facility provided on the basis of obligations for mutual-help purposes of which the borrower is only required to return the principal of the loan without any additional incentives or profit margins, unless the voluntary borrower exceeds the payment. If there is any surplus in the refund, the Islamic bank will refund being the source of the qardhul hasan financing fund. This funding can be used to finance the poor economic growth (dhuafa) in the form of working capital, especially for middle and lower sector customers who are still difficult to get help and loans from banks. If this can be managed properly, it will create an effect on the macroeconomic scale. Economic empowerment on a small-scale with the concept of community empowerment is one of the right solutions to overcome poverty in society.

\section{B. PROBLEM STATEMENTS}

From the above explanation, it has been known that Islamic banks have philosophical principles and operational bases integrated with social values and economic activities. Almost all social community observers agree that increasing poverty has an impact on increasing crime rates, the lower level of education and health, can lead to radicalization of state policies and even create fundamentalism in religion. The government must have a strong commitment to 
overcome the problem of this nation poverty. The formulation of the problem in this research are:

a. How is the implementation of interest free loan (Al-qardhul Hasan) by Islamic bank as the realization of the social function of Islamic bank?

b. What is the interest-free loan financing (Al-qardhul Hasan) able to alleviate poverty in Surakarta?

\section{RESEARCH METHODS}

This research is a socio-legal research (non-doctrinal research). In nondoctrinal research, the law is conceptualized as law is what it is (functioning) in society. The research was conducted in Islamic banks in Surakarta city at Bank Muamalat, Bank Syariah Mandiri and Bank Tabungan Negara Syariah. The data that researchers used in this study comes from primary data. Primary data is data obtained directly from the first data source at the research site or research object. Primary data is obtained from the respondents in this case the policy makers, and the community directly related to the object of research. The data analysis technique used in this legal research uses qualitative method with interactive model (interactive model of analysis). Qualitative data analysis are used an ongoing, repetitive and ongoing effort. Data reduction, data presentation and conclusion are successful sequence as a series of mutual follow-on analysis activities. This analysis model includes three stages: data reduction phase, data presentation stage and verification phase or conclusion.

\section{RESEARCH RESULTS AND DISCUSSION}

\section{A. Products Distribution of Funds in Islamic Bank in Surakarta.}

\section{Indonesia’s Islamic Bank Product}

The products Indonesia's Islamic Bank applied gradually from the beginning of BMI until december 2000 by applying three product categories, they are; first, fund-raising product, includes savings, trend savings, and arofah savings, deposits, and demand deposits. Second, products are channeling of funds, example sale and purchase, buy, profit sharing, and leasing. Third, service products, including: wakalah, kafalah, hiwalah, rahn, and al-Qordh al-hasan (Annual Report BMI: 1999). 
a. Buying and selling

Buying and selling is a BMI product that includes finance products (fund disbursement). This product run with three basic mechanisms, they are: murabahah, salam, and istisna.

1) Al-Murabahah, the specification that signed by the sale and purchase of murabahah is BMI's implantation to the financing for the purchase of goods inventory, both production and consumption. In this case the bank acts as a seller and a customer as a buyer. Banks and customers must agree on the cost of goods sold, profits, and durations. Then the bank buys the goods ordered and provided to the customer. Then the customer repay according to price and time period agreed. (Yasin, 2009: 190).

2) As-Salam, The specification products of sale and purchase of Salam is usually used as a financing for farmers with a relatively short period of time, which is 2-6 months. Because the purchased by bank are goods such as rice, corn, and chili. Bank does not intend to make it at inventory. Therefore, an agreement is made to the second buyer. The second buyer referred to Bulog, wholesale market trader, wholesaler. This is in Islamic banking known as parallel as-salam.

3) Al-Istishna, the specification of the sale and purchase product of alistishna is applicable for construction finance and short-term manufacturing goods. In this case the bank acts as the buyer while the customer as the seller (maker). Banks can distribute funds gradually in accordance with istishna principles. When the goods are finished, the bank may sell them in installments to other customers for profit.

4) Profit Sharing, This product of BMI funds implements two basic mechanisms: al-Mudharabah and al-Musyarakah.

a) Al-Mudharabah, this product specifications can be applied to both short-term and long-term projects. This concept can also be done for working capital financing such as working capital of trade and services. In this case the bank as the owner of capital (shohibul mall) that provides $100 \%$ capital and customers act as 
managers. If the project is profitable, then profit is divided based on the initial agreement. Meanwhile, if there is a loss caused not because of customer negligence, it becomes a bank risk.

b) Al-Musharakah, This product specification is applicable for project financing, which both of the customers and banks provide funds to finance the project. After the project is completed, the customer returns the funds as well as the profit sharing that has been disbursed to the bank. In addition to financing musharakah projects can also be applied in the venture capital scheme. Investment is made for a certain period and after that the bank invests both briefly and gradually. This concept is based on the musharakah normative concept (Saeed, 1996: 59-52) which is a contract of cooperation between two or more parties for a particular business. Each party contributes the fund (charity) with the provision that the benefits and risks will be borne by two parties in accordance with the agreement.

Analysis of each product included three, they are methods and mechanisms of product formulation, product existence. A product tends to the concept of fiqh muamalah normative, the concept of conventional banking, or different from both. The third is the essence of the product, including three things, namely a product when viewed a) from the syar'i aspect emphasizes the concept of which school is used and how the consideration of fiqh's proposals, b) from the economic aspect focuses on economic considerations and how the arguments of the use of those considerations, and C) from the political aspect of looking at political considerations and arguments about the use of these considerations.

The BMI products and services are:

a. The funds. Includes: demand deposits (current accounts and current accounts of institutions), savings (muamalat savings, postal savings, pilgrimage savings plus, hajj savings, muamalat umroh savings, savings, bancassurance), deposits (mudharabah deposits and deposits fulinves) Hi-1000, tariff and FAQ (funding). 
b. Financing includes consumers (shari'ah, automalat, bailout portion, muamalat umroh, cooperative members), work's capital (working capital, syari'ah LKM, syari'ah account), investment (investment financing), FAQ (financing)

c. Services include: international banking (remittance, trade finance, investment service), transfer, 24 hour service (sms banking, salamumalat, muamalat Mobile, internet banking).

\section{B. Fund Output Products at Bank Syari'ah Mandiri}

In its operations, Bank Syariah Mandiri uses several schemes that are compatible with syariah (Islamic):

1. Funding / Fundraising are Wadiah and mudharabah.

Wadiah (deposit); by the wadiah scheme, customers deposit their funds to Islamic banks. Customers allow their funds to be utilized by Islamic banks for various purposes (which are Shariah compliant). However, if the customer wants to withdraw funds, the Islamic bank is obliged to provide the fund. Generally wadiah schemes are used in demand products and some types of savings. BSM uses this scheme for BSM Giro, BSM TabunganKu and BSM Simpatik Savings.

Mudharabah (investment); by mudaraba scheme, customers invest their funds to Islamic banks being managed. In this scheme, BSM functions as an investment manager for fund customers. The Customer entrusts the management of such funds for profitable (and Shari'ah) business purposes. The profit from the business will be shared between the customer of the fund and BSM in accordance with the pre-disbursed ratio. BSM uses this scheme for BSM Deposits, BSM Savings, BSM Savings Planning, BSM Tabungan Mabrur, BSM Tabungan Investa Cendekia and BSM Savings Account.

2. Financing or Distribution of funds consisting of Murabahah, ijarah, istishna, mudarabah, musharaka etc.

a. Murabaha; It is a buying and selling agreement between the customer and the Islamic bank. The Islamic bank will purchase the customer's goods and then sell the goods to the customer with an agreed margin. 
The selling price (principal + margin) will be repaid every month for the agreed term between the customers and the Islamic bank. Because the selling price has been agreed in advance, the customer's installment is fixed during the term of financing. Almost all BSM consumptive financing (BSM Griya, BSM Oto) uses this scheme. This scheme is also widely used BSM in financing working capital or investment in the form of goods. Approximately $70 \%$ of Islamic bank financing using murabaha scheme.

b. Ijarah; It is a leasing agreement between the customer and the Islamic bank. Islamic banks finance needs of services or benefits of a good and leased to customers. Generally, the customer pays the leasing to the Islamic bank every month with the amount already agreed upon. BSM applies this scheme to BSM Funding Eduka (financing for college) and BSM Umrah Financing. Some investment financing also uses the ijarah scheme, especially the scheme of the tamlik bits of muntahiya (IMBT).

c. Istishna; It is a buying and selling agreement between the customer and the Islamic bank, but the goods to be purchased are in the process of making. Islamic banks finance the making of such goods and get payments from customers for financing of goods plus a profit margin. The principal and margin payments to Islamic banks are not at the same time at the end of the period, but are repaid in accordance with the agreement. Generally Islamic banks utilize this scheme for construction finance.

d. Mudharabah, is a profit-sharing contract, of which the Islamic bank fully covers the needs of business capital / investment.

e. Musharaka; It is a profit-sharing contract, whereby Islamic banks do not fully cover the business / investment capital (usually around 70 s.d. $80 \%)$.

3. Services: Wakalah, rahn, kafalah, sharf and so on.

a. Wakalah; Wakalah means trust / representation. This means that BSM works to represent customers in doing things. BSM applies this scheme to various services such as money transfer, L / C, SKBDN and so on. 
b. Rahn; Rahn means pawn. This means that Islamic banks lend money (qardh) to customers with the guarantee deposited to the bank's Islamic customer. Islamic banks charge such deposit fees to cover the costs and benefits of Islamic banks. BSM apply this scheme to BSM Pawn Gold iB.

c. Kafalah; with the kafalah scheme, Islamic banks guarantee their clients. If something happens with the customer, the Islamic bank will be responsible to the 3rd party according to the initial agreement.BSM applies this scheme to BSM Bank Guarantee products.

d. Sharf; It is a money changer. BSM applies this scheme to Rupiah currency exchange services with other currencies, such as USD, MYR, JPY, etc.

\section{Funds Disbursement Products at BTN Syari'ah}

Some of BTN Syari'ah's products include:

a. Working Capital Financing BTN iB

Financing products are provided to meet the needs of working capital expenditures of customers, institutions / companies using the principle of musharabah contract (profit sharing), with a refund plan based on customer cashflow capability.

b. Construction Financing BTN iB

Finance products are provided to meet the needs of working capital expenditures of housing developers to build housing projects using Musyarakah (profit sharing) scheme, with a payback plan based on projected customer cashflow capability.

c. Investment Financing of BTN iB

Financing products provided to fulfill the needs of capital expenditures of companies / institutions using Murabahah (trading) and / or Musyarakah (Profit Sharing) principles, with a payback plan based on the projection of customer cash flow capability.

d. Benefits of BTN iB

The benefits of BTN iB are personal consumptive financing specially indicated for employees and retirees whose pension benefits are paid through BTN Syari'ah Payroll services. 
By looking at various Islamic banking products of Bank Muamalat, Bank Syariah Mandiri and Bank Tabungan Negara Syariah not provides service of Qordhul hasan product. Qordhul hasan, as one form of Islamic banking business which is still becoming an ideal in syari'ah banking, this concept is apparently still far from the expected reality. This can be seen in the practice of syari'ah banking, where the bank does not implement the qordhul hasan financing scheme or when the bank applies only in a little quantities.

As an example is the result of an interview with BTN Shari'ah employee which states that BTN Syari'ah does not issue qordhul hasan product, no financing qordhul hasan purely. The existing agreement is aqad qordh that is to provide loans to customers by imposing administrative costs. An example of this aqad qordh is in terms of multijasa (education, sickness, marriage and so on) and bailout of hajj. Banks are more focused on running products that are profitable. In Bank Muamalat there is no Qordhul Hasan product and in Bank Syariah Mandiri also does not exist even though around 2008-2009 it never existed but now there is no such program.

\section{B. Effectiveness of Interest-Free Loan Financing (Qardhul Hasan) as the Implementation of the Social Function of Syari'ah Banking in the Framework of Poverty Alleviation in Surakarta}

Al-Qard Hasan is a contract of interest-free loans granted on the basis of liability, on the basis of ta'awun (please help) to those classified as weak in economy, where the borrower is not required to pay back anything except loan capital. Under the agreement, a Islamic banking as a creditor lends to the party (customer) on the condition that the loan receipt will repay the loan at the time specified in the contract agreement with the same amount of return when the loan is granted.

Based on the law, this contract is an offer from God, that for who is willing to help ease the burden of people with good lending, it is Allah who redouble its return. It is written in the Qur'an: "Whoever is willing to lend to Allah Almighty, a good loan will Allah multiply the payment to him with 
multiple folds." (Surat al-Baqarah: 245). The benefits of interest-free loan (Alqardhul Hasan) include:

1. Al-qardhul hasan is a free credit facility provided free of charge. The Customer shall only bear the stamp duty, notary fees and feasibility study costs. The level of bank awareness to customers regardless of their economic level. The Bank treats its customers as business partners that are not only business considerations, but also humanitarian considerations.

2. Enable customers who are in urgent trouble to get short-term bailouts.

3. The existence of social mission will improve the good image in improving community loyalty to sharia banking.

4. reducing poverty by fostering poor and oppressed economic society through the aid of productively directed grants. The funds can be obtained from the loan without interest ie al qardhul hasan whose funds are obtained from zakat.

5. Al-qardhul hasan is also one of the distinguishing features between Islamic banks and conventional banks which contained social missions in addition to commercial missions.

In the reality Islamic bank does not apply qardhul hasan contract so this product has not been able being the solution in effort to eradicate society poverty. The qardhul hasan contract was implemented in the early days of the establishment of Islamic banking. At present banking is more likely to apply products that provide benefits.

\section{E. CLOSING}

1. Financing of Al-qardhul hasan has not got attention from Islamic banking as the realization of the social function of Islamic banking although this program has functioned in the early establishment of Islamic banking. Islamic banking products are more oriented to the program which contains the value of profit.

2. Interest-free loan (Al-qardhul Hasan) has not been able to take a role in eradicating poverty in Surakarta because Al-qardhul Hasan program is considered less suitable by the banking system.

\section{BIBLIOGRAPHY:}




\section{Books:}

Habib Nazir, 2004, Ensiklopedi Ekonomi dan Perbankan Syariah. Bandung: Kafa Publishing.

Lexy. J. Moleong, 2002, Metode Penelitian Kualitatif. Bandung: PT. Remaja Rosdakarya.

Muhammad Syafi'i Antonio. 2001. Bank Syariah Dari Teori ke Praktek. Jakarta: Gema Insani.

Muhammad. 2005. Manajemen Bank Syariah. Yogyakarta: Unit Penerbitan dan Percetakan YKPN.

Mustafa Edwin Nasution. 2006. Pengenalan Ekslusif Ekonomi Islam. Jakarta: PT. Kencana Media Group.

Nurul Huda. 2008. Ekonomi Makro Indonesia (Pendekatan Teoritis). Jakarta: PT. Kencana Media Group.

Soerjono Soekanto. 2006. Pengantar Penelitian Hukum. Jakarta: UI-Press.

Warkum Sumitro. 2004. Asas-asas Perbankan Islam dan Lembaga-lembaga Terkait. Jakarta: PT. Raja Grafindo Persada.

Zainal Arifin. 2000. Memahami Bank Syariah. Jakarta: Alvabet.

Zainuddin Ali. 2007. Hukum Pebankan Syariah. Jakarta: PT. Sinar Grafika.

\section{Regulation:}

Law Number 21 of 2008 On The Sharia Bank. 